\title{
Effect of Cytokinins on the Micropropagation of Carob (Ceratonia siliqua L.) through Shoot Tip Culture
}

\author{
Rabah Saïdi' ${ }^{1}$, Safaâ Rahmouni², Zineb Nejjar El Ansari², Abdelfettah Maouni', Alain Badoc ${ }^{3}$, \\ Ahmed Lamarti ${ }^{*}$ \\ ${ }^{1}$ Department of Matter and Life Sciences, High Normal School, Martil, Morocco \\ ${ }^{2}$ Laboratory of Plant Biotechnology, Biology Department, Faculty of Sciences, Abdelmalek Essaadi University, Tetouan, Morocco \\ ${ }^{3}$ Axe MIB (Molécules d'Intérêt Biologique), Unité de Recherche (Enologie EA 4577, USC 1366 INRA), UFR des Sciences \\ Pharmaceutiques, Université de Bordeaux, ISVV (Institut des Sciences de la Vigne et du Vin), Bordeaux, France \\ Email: *lamarti.ahmed58@gmail.com
}

How to cite this paper: Saïdi, R., Rahmouni, S., El Ansari, Z.N., Maouni, A., Badoc, A. and Lamarti, A. (2019) Effect of Cytokinins on the Micropropagation of Carob (Ceratonia siliqua L.) through Shoot Tip Culture. American Journal of Plant Sciences, 10, 14691481.

https://doi.org/10.4236/ajps.2019.109104

Received: July 20, 2019

Accepted: September 6, 2019

Published: September 9, 2019

Copyright (c) 2019 by author(s) and Scientific Research Publishing Inc. This work is licensed under the Creative Commons Attribution International License (CC BY 4.0).

http://creativecommons.org/licenses/by/4.0/

\begin{abstract}
In order to determine the most suitable cytokinin for the micropropagation of carob (Ceratonia siliqua L.), the effect of four cytokinins: BAP, zeatin, kinetin and 2-iP, was tested on explants derived from young seedlings of seven days. Organogenesis is better in the presence of BAP $(0.5 \mathrm{mg} / \mathrm{l})$, while buds growth is favored by zeatin $(0.5 \mathrm{mg} / \mathrm{l})$. The combination of the most suitable cytokinin (BAP at $0.5 \mathrm{mg} / \mathrm{l}$ ) with IBA improves the caulogenesis when the concentration of this latter is low $(0.1 \mathrm{mg} / \mathrm{l})$; high concentrations of IBA have an inhibitory effect on elongation and neoformation of shoots and leaves. The multiplication and growth of shoots are more favorable on WPM medium in the presence of BAP $(0.5$ and $1 \mathrm{mg} / \mathrm{l})$ alone or combined with $0.5 \mathrm{mg} / \mathrm{l}$ with $\mathrm{GA}_{3}$, while rooting is mainly favored by IBA, especially at $2 \mathrm{mg} / \mathrm{l}$.
\end{abstract}

\section{Keywords}

Carob, Ceratonia siliqua L., Cytokinins, Shoot Tip Culture

\section{Introduction}

This Carob (Ceratonia siliqua L.) is a Fabaceae Caesalpinioideae characteristic of Mediterranean regions and more or less equivalent climates. Generally spontaneous, it is currently cultivated on a large scale for its ecological and economic virtues. It is doing well in most Mediterranean climates despite their irregularity and on different types of soils [1] [2] [3] [4] [5]. 
In Morocco, except of the arid zones, this species is present everywhere, in the same bioclimatic stage as Thuja, Red Juniper, Pistachio tree as well as in the upper part of argan tree. It is more abundant in the Middle Atlas (Khenifra, especially the region of Oued Srou), as well as in the south where it often mixes with Thuya and Phenicia juniper [6]. It is also found in Sais, Anti-Atlas, Northern High Atlas, Central Plateau, Pre-Rif and Western Rif, especially in the region of Chefchaouen, both in the spontaneous and domesticated state, as in Mokrisset Circle [7] [8] [9] [10].

Its aromatic and medicinal properties, wood, ornamental and landscape value, pulp and seeds with multiple uses, make this plant the most performing tree in Morocco [5]. Carob pulp is widely used in food and pharmaceutical industries for its richness in various organic compounds of good quality, in particular reducing sugars, polyphenols and tannins; it is also rich in various mineral elements, such as iron, calcium, sodium, potassium, phosphorus and sulfur [11] [12] [13] [14] [15]. In addition, seeds albumen provides a rubber used in food and pharmaceutical industries [4] [16] [17] [18] [19] [20].

These assets emerge the interest to control propagation techniques of this species by in vitro culture for the production of quality plants. Indeed, since the 1990 s, different types of explants have been used from either young seedlings or adult tree. Also, apex culture from young seedlings has been studied [21] [22] [23] [24]. This technique allows working on explants without prior disinfection and offers several possibilities of multiplication. In addition, shoot tip culture is a simple and fast method for large-scale propagation of carob.

\section{Material and Methods}

\subsection{Explants Origin and Culture Conditions}

Seeds come from mature fruits harvested in August from a vigorous tree in Bni Mtil region, at the edge of Tetouan Chefchaouen road (Morocco). Germination was carried out in flasks containing sterile agar-water $(0.7 \%)$, after disinfection and scarification with $36 \mathrm{~N}$ sulfuric acid for one hour, followed by three successive rinses for $10 \mathrm{~min}$ with sterile distilled water. After one week, germination rate is close to $100 \%$. Apices of young seedlings, whose size is 4 to $5 \mathrm{~mm}$, were cut before epicotyl stage and directly transplanted into $200 \mathrm{ml}$ flasks containing $50 \mathrm{ml}$ of WPM culture medium [25], supplemented with Murashige and Skoog [26] micronutrients and vitamins, $30 \mathrm{~g} / \mathrm{l}$ of sucrose, $0.1 \mathrm{~g} / \mathrm{l}$ of myo-inositol and $0.7 \%$ of agar. $\mathrm{pH}$ was adjusted to 5.8 before autoclaving.

Explants were kept in a culture room with a photoperiod of 16 hours, a luminous intensity of 4000 lux and a temperature of $23^{\circ} \mathrm{C}$ to $25^{\circ} \mathrm{C}$ during the day and $20^{\circ} \mathrm{C}$ at night. Results were evaluated after 30,45 and 60 days.

For each experiment, three replicates on thirty samples $(n=30)$ were carried out successively. Results were compared by analysis of variance (ANOVA) with Duncan's Multiple Range test (coefficient $\alpha=0.05$ ). Shoots were considered undeveloped for a size less than $5 \mathrm{~mm}$ and a number of leaves less than 2 . 


\subsection{Effect of Different Cytokinins}

Four cytokinins: BAP, zeatin, kinetin and 2-iP, at two concentrations: 0.5 and 1 $\mathrm{mg} / \mathrm{l}$ were studied on WPM basal medium.

\subsection{Effect of BAP-IBA Combination}

In the first experiments, different concentrations of BAP $(0.1,0.3,0.5,1$ and 1.5 $\mathrm{mg} / \mathrm{l})$ were combined with IBA $(0.1 \mathrm{mg} / \mathrm{l})$ on WPM medium. In the second step, the most favorable BAP concentration $(0.5 \mathrm{mg} / \mathrm{l})$ was selected and IBA concentration was varied $(0.1,0.2,0.5$ and $1 \mathrm{mg} / \mathrm{l})$.

\subsection{Multiplication and Elongation of Shoots Obtained from Apex Culture}

In the first step, multiplication of shoots obtained from apex culture was accomplished on WPM and MS media, in the presence of three concentrations of BAP: $0.5,1$ and $1.5 \mathrm{mg} / \mathrm{l}$. Then, the most adequate BAP concentration $(0.5 \mathrm{mg} / \mathrm{l})$ was combined with different concentrations of $\mathrm{GA}_{3}: 0.1,0.2,0.3,0.5,0.8$ and $1 \mathrm{mg} / \mathrm{l}$ on WPM medium. In parallel with the study of shoot development, a follow-up of their elongation after each week was performed with the combinations IBA $(0.1 \mathrm{mg} / \mathrm{l})+\operatorname{BAP}(0.1,0.3,0.5,1.5 \mathrm{mg} / \mathrm{l})$ and $\mathrm{BAP}(0.5 \mathrm{mg} / \mathrm{l})+\mathrm{GA}_{3}(0,0.3,0.5$ and $1 \mathrm{mg} / \mathrm{l})$.

\subsection{Rooting}

Shoots rooting after the multiplication phase was obtained after its induction in the dark by the auxins for one week on a half-diluted medium, composed of MS macronutrients, micronutrients and vitamins, sucrose (3\%), myo-inositol (0.1 $\mathrm{g} / \mathrm{l}$ ) and agar (0.7\%). Different auxins (IBA, IAA, NAA and 2,4-D) were tested at 1 and $2 \mathrm{mg} / \mathrm{l}$. Shoots were then transferred to PGR free medium in the presence of light. Results were evaluated after 30 days.

\subsection{Plantlets Acclimatization}

After thirty days, vigorously rooted plantlets were transferred to pots containing peat and were sprayed with a $1 \%$ Benlate solution. Transparent plastic bags covering each plantlet ensured high humidity. Cultures were watered once a week with 1/2 MS mineral solution. They were kept in the culture room under the same conditions as before.

\section{Results}

\subsection{Effect of Cytokinins}

Shoot size varies markedly according to cytokinin type and concentration. Zeatin significantly promotes growth in length at $0.5 \mathrm{mg} / \mathrm{l}$, whatever the measurement period. The size of the shoots is a little weaker with $1 \mathrm{mg} / \mathrm{l}$ of zeatin and on the contrary minimal with $1 \mathrm{mg} / \mathrm{l}$ of BAP and $0.5 \mathrm{mg} / \mathrm{l}$ of kinetin (Table 1, Figure $1(b))$. 
Table 1. Effect of cytokinins $(0.5$ and $1 \mathrm{mg} / \mathrm{l})$ on carob shoots elongation and neoformation.

\begin{tabular}{|c|c|c|c|c|c|c|c|}
\hline \multicolumn{2}{|c|}{$\begin{array}{l}\text { Cytokinins } \\
(\mathrm{mg} / \mathrm{l})\end{array}$} & \multicolumn{3}{|c|}{ Shoots size (mm) } & \multicolumn{3}{|c|}{ Number of shoots } \\
\hline & & 30 days & 45 days & 60 days & 30 days & 45 days & 60 days \\
\hline Control & 0 & $7.3 \pm 1.8 \mathrm{e}$ & $9.0 \pm 2.2 \mathrm{f}$ & $10.0 \pm 2.0 \mathrm{~g}$ & $1 \mathrm{~d}$ & $1.10 \pm 0.16 \mathrm{f}$ & $1.20 \pm 0.14 \mathrm{e}$ \\
\hline \multirow{2}{*}{ BAP } & 0.5 & $11.8 \pm 2.1 \mathrm{c}$ & $14.6 \pm 3.6 \mathrm{c}$ & $16.7 \pm 4.6 \mathrm{~cd}$ & $3.43 \pm 1.61 \mathrm{a}$ & $4.48 \pm 1.76 \mathrm{a}$ & $5.32 \pm 1.80 \mathrm{a}$ \\
\hline & 1 & $9.7 \pm 2.1 \mathrm{~d}$ & $10.2 \pm 1.8 \mathrm{ef}$ & $13.6 \pm 2.3 \mathrm{ef}$ & $1.86 \pm 0.57 b$ & $2.32 \pm 0.71 b c$ & $2.85 \pm 0.87 b c$ \\
\hline \multirow{2}{*}{ Zeatin } & 0.5 & $19.1 \pm 3.9 \mathrm{a}$ & $20.8 \pm 4.1 \mathrm{a}$ & $21.4 \pm 4.3 \mathrm{a}$ & $1.61 \pm 0.61 \mathrm{~b}$ & $2.70 \pm 0.54 b$ & $2.91 \pm 0.72 \mathrm{~b}$ \\
\hline & 1 & $15.9 \pm 3.6 b$ & $17.2 \pm 3.6 \mathrm{~b}$ & $18.7 \pm 3.7 \mathrm{~b}$ & $1.53 \pm 0.44 \mathrm{bc}$ & $2.04 \pm 0.38 \mathrm{~cd}$ & $2.22 \pm 0.68 \mathrm{~d}$ \\
\hline \multirow{2}{*}{ Kinetin } & 0.5 & $7.5 \pm 3.6 \mathrm{e}$ & $11.1 \pm 3.4 \mathrm{de}$ & $12.1 \pm 4.0 \mathrm{f}$ & $1.11 \pm 0.06 \mathrm{~cd}$ & $1.21 \pm 0.13 \mathrm{f}$ & $1.23 \pm 0.12 \mathrm{e}$ \\
\hline & 1 & $9.2 \pm 2.2 \mathrm{~d}$ & $14.0 \pm 3.2 \mathrm{c}$ & $15.0 \pm 6.1 \mathrm{de}$ & $1 \mathrm{~d}$ & $1.31 \pm 0.15$ ef & $1.50 \pm 0.11 \mathrm{e}$ \\
\hline \multirow{2}{*}{ 2-iP } & 0.5 & $8.2 \pm 1.0 \mathrm{de}$ & $14.1 \pm 3.2 \mathrm{c}$ & $17.1 \pm 3.8 \mathrm{bc}$ & $1 \mathrm{~d}$ & $1.43 \pm 0.26 \mathrm{ef}$ & $1.49 \pm 0.34 \mathrm{e}$ \\
\hline & 1 & $11.3 \pm 2.1 \mathrm{c}$ & $12.3 \pm 2.4 \mathrm{~d}$ & $15.3 \pm 3.1 \mathrm{cde}$ & $1.12 \pm 0.09 \mathrm{~cd}$ & $\mathrm{~d} 1.75 \pm 0.27 \mathrm{de}$ & $2.43 \pm 0.10 \mathrm{~cd}$ \\
\hline
\end{tabular}

The data represent mean \pm SE of replicates $(n=3)$. Values in the same rows carrying different letters are significantly different between treatments and compared by Duncan's multiple range tests at $\mathrm{p} \leq 0.05$.

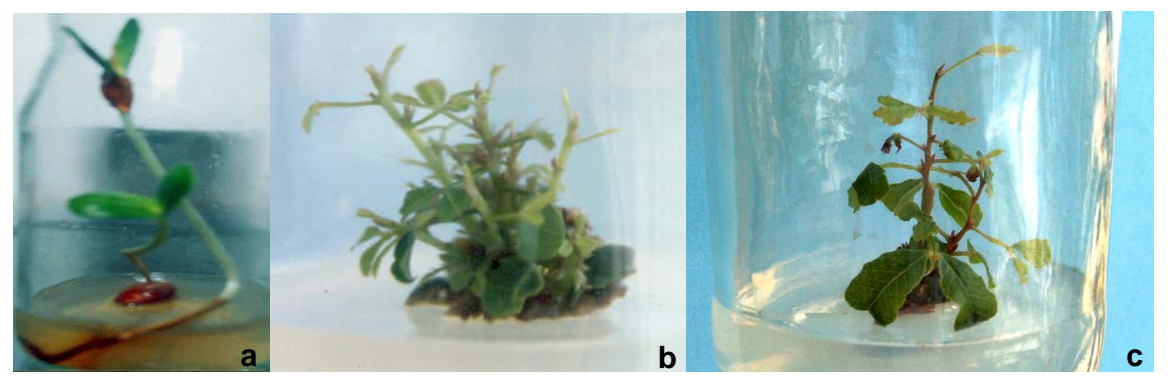

Figure 1. Initiation phase: (a) in vitro germination of seeds after 7 days, (b) one-month-old plantlet (WPM, $0.5 \mathrm{mg} / \mathrm{l}$ of BAP), (c) one-month-old plantlet (WPM, $0.3 \mathrm{mg} / \mathrm{l}$ of BAP and $0.1 \mathrm{mg} / \mathrm{l}$ of IBA).

Neoformation of shoots and leaves is favored by the BAP, significantly at 0.5 $\mathrm{mg} / \mathrm{l}$ from the 30th day. Zeatin is in the second place, significantly at $0.5 \mathrm{mg} / \mathrm{l}$. Kinetin and 2-iP are not very effective with more or less similar results to the control without PGR. As well, 2-iP favors undeveloped explants (Table 2).

\subsection{Effect of BAP-IBA Combination}

In the presence of IBA $(0.1 \mathrm{mg} / \mathrm{l})$, shoots growth depends on BAP, but seems to be unaffected by its concentration: their size is between 14.8 and $16.7 \mathrm{~mm}$ and forms the same statistical unit for the five concentrations studied, whereas in the absence of BAP, it is only $12.4 \mathrm{~mm}$. The combination BAP $(0.5 \mathrm{mg} / \mathrm{l})+\mathrm{IBA}(0.1$ $\mathrm{mg} / \mathrm{l}$ ) promotes shoots and leaves formation. Moving away from this concentration of BAP, the number of shoots and leaves decreases (Table 3, Figure 1(c)).

The combination of other AIB concentrations with BAP $(0.5 \mathrm{mg} / \mathrm{l})$ does not improve shoot growth or caulogenesis. The previously studied combination BAP $(0.5 \mathrm{mg} / \mathrm{l})+\mathrm{AIB}(0.1 \mathrm{mg} / \mathrm{l})$ remains statistically the most favorable for shoots 
Table 2. Effect of cytokinins $(0.5$ and $1 \mathrm{mg} / \mathrm{l})$ on carob leaves neoformation and shoots development.

\begin{tabular}{|c|c|c|c|c|c|c|c|}
\hline \multicolumn{2}{|c|}{$\begin{array}{l}\text { Cytokinins } \\
\text { (mg/l) }\end{array}$} & \multicolumn{3}{|c|}{ Number of leaves by plantlet } & \multicolumn{3}{|c|}{$\begin{array}{l}\% \text { of undeveloped } \\
\text { plantlets }<5 \mathrm{~mm}\end{array}$} \\
\hline & & 30 days & 45 days & 60 days & 30 days & 45 days & 60 days \\
\hline Control & 0 & $2.20 \pm 0.68 \mathrm{~d}$ & $3.33 \pm 1.03 \mathrm{~d}$ & $3.73 \pm 1.12 \mathrm{e}$ & $11.11 \mathrm{~b}$ & $7.14 \mathrm{ab}$ & $7.14 \mathrm{a}$ \\
\hline \multirow{2}{*}{ BAP } & 0.5 & $11.01 \pm 2.01 \mathrm{a}$ & $16.42 \pm 3.01 \mathrm{a}$ & $20.91 \pm 3.82 \mathrm{a}$ & $7.74 \mathrm{~b}$ & $3.54 \mathrm{bc}$ & $0 \mathrm{bc}$ \\
\hline & 1 & $7.25 \pm 1.16 b$ & $9.61 \pm 1.21 \mathrm{~b}$ & $14.42 \pm 1.27 \mathrm{~b}$ & $10.52 \mathrm{~b}$ & $6.66 \mathrm{ab}$ & $6.25 \mathrm{a}$ \\
\hline \multirow{2}{*}{ Zeatin } & 0.5 & $5.92 \pm 0.84 \mathrm{bc}$ & $9.14 \pm 1.05 b$ & $11.17 \pm 1.01 \mathrm{c}$ & $12.16 \mathrm{~b}$ & $4.11 \mathrm{abc}$ & $3.88 \mathrm{ab}$ \\
\hline & 1 & $4.86 \pm 0.78 c$ & $6.90 \pm 0.86 c$ & $10.08 \pm 0.89 c$ & $10.25 \mathrm{~b}$ & $5.14 \mathrm{abc}$ & $4.09 \mathrm{abc}$ \\
\hline \multirow{2}{*}{ Kinetin } & 0.5 & $2.53 \pm 0.41 \mathrm{~d}$ & $3.20 \pm 0.80 \mathrm{~d}$ & $3.96 \pm 0.76 \mathrm{e}$ & $11.11 \mathrm{~b}$ & $6.25 \mathrm{ab}$ & $6.25 \mathrm{a}$ \\
\hline & 1 & $2.40 \pm 0.44 \mathrm{~d}$ & $3.42 \pm 0.38 \mathrm{~d}$ & $4.44 \pm 0.54 \mathrm{de}$ & $5.32 \mathrm{~b}$ & $0 \mathrm{~b}$ & $0 \mathrm{bc}$ \\
\hline \multirow{2}{*}{ 2-iP } & 0.5 & $2.02 \pm 0.34 \mathrm{~d}$ & $3.13 \pm 0.66 \mathrm{~d}$ & $4.05 \pm 0.47 \mathrm{e}$ & $23.12 \mathrm{a}$ & $9.18 \mathrm{a}$ & $7.17 \mathrm{a}$ \\
\hline & 1 & $2.51 \pm 0.39 \mathrm{~d}$ & $4.87 \pm 0.40 \mathrm{~d}$ & $5.91 \pm 0.27 \mathrm{~d}$ & $29.40 \mathrm{a}$ & $0 \mathrm{~b}$ & $0 \mathrm{bc}$ \\
\hline
\end{tabular}

The data represent mean \pm SE of replicates $(n=3)$. Values in the same rows carrying different letters are significantly different between treatments and compared by Duncan's multiple range tests at $\mathrm{p} \leq 0.05$.

Table 3. Effect of different concentrations of BAP combined to IBA $(0.1 \mathrm{mg} / \mathrm{l})$ on carob apex development.

\begin{tabular}{ccccc}
\hline $\begin{array}{c}\text { BAP } \\
(\mathrm{mg} / \mathbf{l})\end{array}$ & $\begin{array}{c}\text { Shoots size } \\
(\mathrm{mm})\end{array}$ & $\begin{array}{c}\text { Shoots number par } \\
\text { plantlet }\end{array}$ & $\begin{array}{c}\text { Number of leaves } \\
\text { by plantlet }\end{array}$ & $\begin{array}{c}\text { \% of plantlets } \\
<5 \mathrm{~mm}\end{array}$ \\
\hline $\mathbf{0}$ & $12.4 \pm 1.2 \mathrm{~b}$ & $1.00 \pm 0 \mathrm{~d}$ & $3.43 \pm 1.15 \mathrm{~d}$ & $15.38 \mathrm{a}$ \\
$\mathbf{0 . 1}$ & $16.7 \pm 2.1 \mathrm{a}$ & $1.50 \pm 0.49 \mathrm{~d}$ & $4.30 \pm 1.21 \mathrm{~d}$ & $13.4 \mathrm{ab}$ \\
$\mathbf{0 . 3}$ & $16.0 \pm 1.9 \mathrm{a}$ & $3.22 \pm 1.02 \mathrm{c}$ & $10.52 \pm 2.18 \mathrm{c}$ & $11.15 \mathrm{abc}$ \\
$\mathbf{0 . 5}$ & $15.1 \pm 1.4 \mathrm{a}$ & $5.90 \pm 1.42 \mathrm{a}$ & $15.73 \pm 2.87 \mathrm{a}$ & $6.44 \mathrm{c}$ \\
$\mathbf{1}$ & $15.5 \pm 1.5 \mathrm{a}$ & $4.11 \pm 1.13 \mathrm{~b}$ & $13.78 \pm 2.45 \mathrm{~b}$ & $7.07 \mathrm{c}$ \\
$\mathbf{1 . 5}$ & $14.8 \pm 1.2 \mathrm{a}$ & $3.80 \pm 1.16 \mathrm{bc}$ & $12.40 \pm 1.98 \mathrm{~b}$ & $8.25 \mathrm{bc}$ \\
\hline
\end{tabular}

The data represent mean \pm SE of replicates $(n=3)$. Values in the same rows carrying different letters are significantly different between treatments and compared by Duncan's multiple range tests at $\mathrm{p} \leq 0.05$.

elongation and development. Other concentrations give more or less similar values. Increasing IBA concentration doesn't favor shoots neoformation and leaves multiplication (Table 4).

\subsection{Multiplication and Elongation of Shoots Obtained from Apex Culture}

\subsubsection{Multiplication}

Shoot growth is not strongly influenced by the choice between WPM and MS media. Shoots size and the number of leaves are significantly higher in 0.5 and 1 $\mathrm{mg} / \mathrm{l} \mathrm{BAP}$ compared to $1.5 \mathrm{mg} / \mathrm{l}$. WPM medium tends to give more shoots than MS medium (Table 5).

The combination of $\mathrm{GA}_{3}$ with BAP slightly increases shoots size compared to the control (without $\mathrm{GA}_{3}$ ), especially at concentrations between 0.3 and $0.8 \mathrm{mg} / \mathrm{l}$, which give similar values (Table 6, Figure 2(a)).

Shoots neoformation is inhibited by high and low concentrations of $\mathrm{GA}_{3}$, 
Table 4. Effect of different IBA concentrations combined to BAP $(0.5 \mathrm{mg} / \mathrm{l})$ on carob apex development.

\begin{tabular}{ccccc}
\hline $\begin{array}{c}\text { IBA concentration } \\
(\mathrm{mg} / \mathbf{l})\end{array}$ & $\begin{array}{c}\text { Plantlets size } \\
(\mathrm{mm})\end{array}$ & $\begin{array}{c}\text { Number of shoots Number of leaves } \\
\text { per plantlet }\end{array}$ & $\begin{array}{c}\text { \% of undeveloped } \\
\text { plantlets }<5 \mathrm{~mm}\end{array}$ \\
\hline $\mathbf{0}$ & $12.3 \pm 0.8 \mathrm{c}$ & $3.61 \pm 1.01 \mathrm{bc}$ & $10.79 \pm 1.96 \mathrm{~cd}$ & $8.82 \mathrm{a}$ \\
$\mathbf{0 . 1}$ & $17.9 \pm 1.5 \mathrm{a}$ & $5.98 \pm 1.32 \mathrm{a}$ & $16.02 \pm 2.54 \mathrm{a}$ & $7.37 \mathrm{a}$ \\
$\mathbf{0 . 2}$ & $16.1 \pm 1.4 \mathrm{~b}$ & $4.81 \pm 1.02 \mathrm{~b}$ & $13.00 \pm 2.04 \mathrm{~b}$ & $7.45 \mathrm{a}$ \\
$\mathbf{0 . 5}$ & $15.4 \pm 0.9 \mathrm{~b}$ & $3.63 \pm 1.10 \mathrm{c}$ & $11.81 \pm 1.89 \mathrm{bc}$ & $8.26 \mathrm{a}$ \\
$\mathbf{1}$ & $15.8 \pm 1.1 \mathrm{~b}$ & $3.60 \pm 0.09 \mathrm{c}$ & $9.10 \pm 1.67 \mathrm{~d}$ & $10.22 \mathrm{a}$ \\
\hline
\end{tabular}

The data represent mean \pm SE of replicates $(n=3)$. Values in the same rows carrying different letters are significantly different between treatments and compared by Duncan's multiple range tests at $\mathrm{p} \leq 0.05$.

Table 5. Effect of WPM and MS media on the multiplication of carob plantlets from apex culture.

\begin{tabular}{cccccc}
\hline & $\begin{array}{c}\text { BAP } \\
(\mathrm{mg} / \mathrm{l})\end{array}$ & $\begin{array}{c}\text { Plantlets size } \\
(\mathrm{mm})\end{array}$ & Shoots number & $\begin{array}{c}\text { Number of leaves } \\
\text { by plantlet }\end{array}$ & $\begin{array}{c}\text { \% of undeveloped } \\
\text { plantlets }<5 \mathrm{~mm}\end{array}$ \\
\hline WPM & $\mathbf{0 . 5}$ & $12.5 \pm 1.3 \mathrm{a}$ & $5.59 \pm 1.14 \mathrm{a}$ & $3.94 \pm 0.48 \mathrm{a}$ & 0 \\
MS & $12.7 \pm 1.5 \mathrm{a}$ & $4.01 \pm 0.74 \mathrm{~b}$ & $3.93 \pm 0.57 \mathrm{a}$ & 0 \\
\hline WPM & 1 & $12.0 \pm 1.5 \mathrm{a}$ & $5.68 \pm 1.17 \mathrm{a}$ & $4.02 \pm 0.5 \mathrm{a}$ & 0 \\
MS & & $12.1 \pm 1.3 \mathrm{a}$ & $5.37 \pm 0.98 \mathrm{a}$ & $3.78 \pm 0.44 \mathrm{~b}$ & 0 \\
\hline WPM & & $10.8 \pm 0.8 \mathrm{~b}$ & $5.22 \pm 1.05 \mathrm{a}$ & $3.13 \pm 0.54 \mathrm{c}$ & 0 \\
MS & 1.5 & $10.2 \pm 0.7 \mathrm{~b}$ & $3.06 \pm 0.45 \mathrm{c}$ & $2.05 \pm 0.60 \mathrm{~d}$ & 0 \\
\hline
\end{tabular}

The data represent mean \pm SE of replicates $(n=3)$. Values in the same rows carrying different letters are significantly different between treatments and compared by Duncan's multiple range tests at $\mathrm{p} \leq 0.05$.

Table 6. Effect of different $\mathrm{GA}_{3}$ concentrations combined to $0.5 \mathrm{mg} / \mathrm{l} \mathrm{BAP}$ on carob shoots multiplication from apex culture.

\begin{tabular}{ccccc}
\hline $\begin{array}{c}\mathrm{GA}_{3} \text { concentration } \\
(\mathrm{mg} / \mathrm{l})\end{array}$ & $\begin{array}{c}\text { Plantlets } \\
\text { size }(\mathrm{mm})\end{array}$ & Shoots number & $\begin{array}{c}\text { Number of leaves } \\
\text { by plantlet }\end{array}$ & $\begin{array}{c}\text { \% of undeveloped } \\
\text { plantlets }<5 \mathrm{~mm}\end{array}$ \\
\hline $\mathbf{0}$ & $12.4 \pm 1.2 \mathrm{c}$ & $5.29 \pm 0.98 \mathrm{a}$ & $3.88 \pm 0.44 \mathrm{~b}$ & 0 \\
$\mathbf{0 . 1}$ & $12.6 \pm 1.3 \mathrm{bc}$ & $2.43 \pm 0.32 \mathrm{c}$ & $3.90 \pm 0.58 \mathrm{~b}$ & 0 \\
$\mathbf{0 . 2}$ & $12.6 \pm 1.2 \mathrm{bc}$ & $2.62 \pm 0.29 \mathrm{bc}$ & $3.93 \pm 0.52 \mathrm{~b}$ & 0 \\
$\mathbf{0 . 3}$ & $14.5 \pm 1.9 \mathrm{ab}$ & $4.67 \pm 0.45 \mathrm{a}$ & $3.15 \pm 0.43 \mathrm{c}$ & 0 \\
$\mathbf{0 . 5}$ & $15.4 \pm 1.8 \mathrm{a}$ & $4.50 \pm 0.62 \mathrm{a}$ & $3.29 \pm 0.41 \mathrm{c}$ & 0 \\
$\mathbf{0 . 8}$ & $14.3 \pm 1.6 \mathrm{ab}$ & $3.50 \pm 0.34 \mathrm{~b}$ & $4.78 \pm 0.50 \mathrm{a}$ & 0 \\
1 & $13.22 \pm 1.5 \mathrm{bc}$ & $3.12 \pm 0.25 \mathrm{bc}$ & $4.31 \pm 0.41 \mathrm{a}$ & 0
\end{tabular}

The data represent mean \pm SE of replicates $(n=3)$. Values in the same rows carrying different letters are significantly different between treatments and compared by Duncan's multiple range tests at $\mathrm{p} \leq 0.05$.

while moderate concentrations $(0.3$ and $0.5 \mathrm{mg} / \mathrm{l})$ give a number of shoots more or less similar to that of the control. The number of leaves is greater for the highest concentrations of $\mathrm{GA}_{3}(0.7$ and $1 \mathrm{mg} / \mathrm{l})$.

The combination of $\mathrm{GA}_{3}$ with BAP increases slightly the shoot size compared 


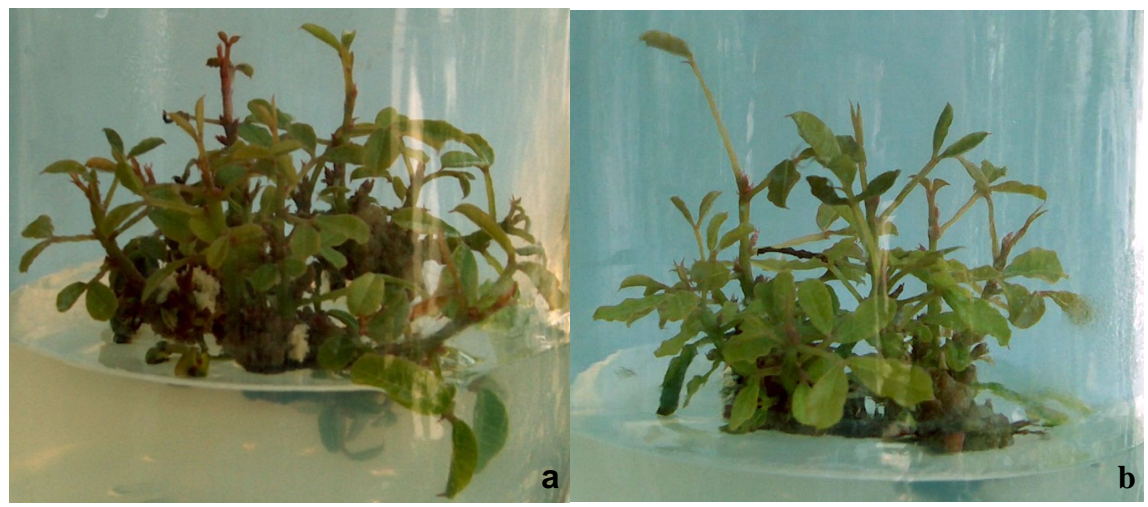

Figure 2. Multiplication phase: one-month-old plantlets obtained after the culture of shoots derived from apical buds on WPM medium [(a), $0.5 \mathrm{mg} / \mathrm{l} \mathrm{BAP}$ and $0.5 \mathrm{mg} / \mathrm{l} \mathrm{GA}_{3}$; (b), $0.5 \mathrm{mg} / \mathrm{l} \mathrm{BAP}$ and $0.1 \mathrm{mg} / \mathrm{l} \mathrm{IBA]}$.

to the control (without GA3), especially at concentrations between 0.3 and 0.8 $\mathrm{mg} / \mathrm{l}$, which give similar values (Table 6, Figure 2(a)).

Neoformation of shoots is inhibited by high and low concentrations of $\mathrm{GA}_{3}$, while moderate concentrations $(0.3$ and $0.5 \mathrm{mg} / \mathrm{l})$ give a number of shoots more or less similar to that of the control. Multiplication of leaves is better for the highest concentrations of $\mathrm{GA}_{3}(0.7$ and $1 \mathrm{mg} / \mathrm{l})$.

\subsubsection{Elongation}

Shoots elongation after one month is usually more remarkable between the second and third week. The combination BAP $(0.1 \mathrm{mg} / \mathrm{l})+\mathrm{IBA}(0.1 \mathrm{mg} / \mathrm{l})$ seems to be the most favorable for shoot elongation. It is the same for moderate concentrations of $\mathrm{GA}_{3}(0.3$ to $0.5 \mathrm{mg} / \mathrm{l})$ combined with BAP $(0.5 \mathrm{mg} / \mathrm{l})$. However, it should be noted that shoot elongation tends to fade away as it approaches the fourth week (Figure 2(b), Figure 3 and Figure 4).

\subsection{Rooting}

IBA was the most suitable auxin for rooting of shoots resulting from the multiplication by apex culture. $2 \mathrm{mg} / \mathrm{l}$ concentration gave a rooting percentage close to $90 \%$ and a satisfactory roots size $(6 \mathrm{~cm})$. Also, $1 \mathrm{mg} / \mathrm{l}$ gave good results, in particular for the neoformation of roots (6 per plantlet) and their size. However, IAA at $2 \mathrm{mg} / \mathrm{l}$, NAA and 2,4-D do not favor rooting (Table 7, Figure 5(a)).

\subsection{Acclimatization of Rooted Plantlets}

Acclimatization of young plantlets after the multiplication phase was successful with a percentage of $80 \%$. Sometimes, plantlets suffer leaf necrosis and wilt. After acclimatization and transfer to the soil, young plants are generally well maintained (Figure 5(b)).

\section{Discussion}

The study of the effect of cytokinins on the culture of carob apex showed that 


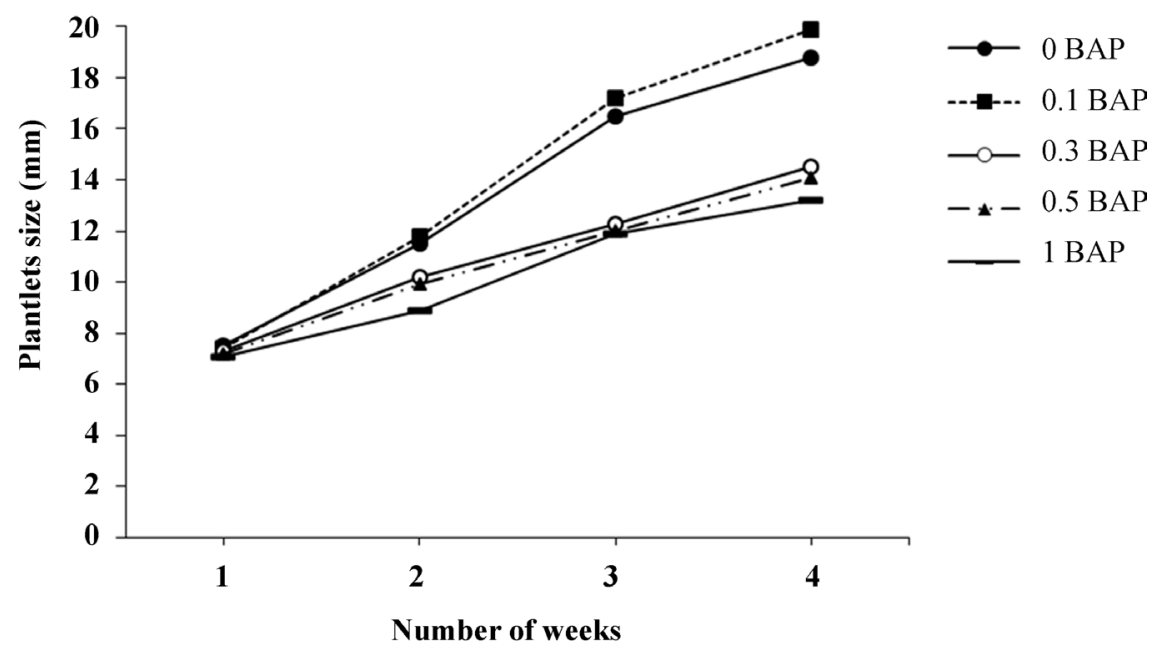

Figure 3. Effect of BAP (mg/l) combined to IBA $(0.1 \mathrm{mg} / \mathrm{l})$ on carob shoots elongation.

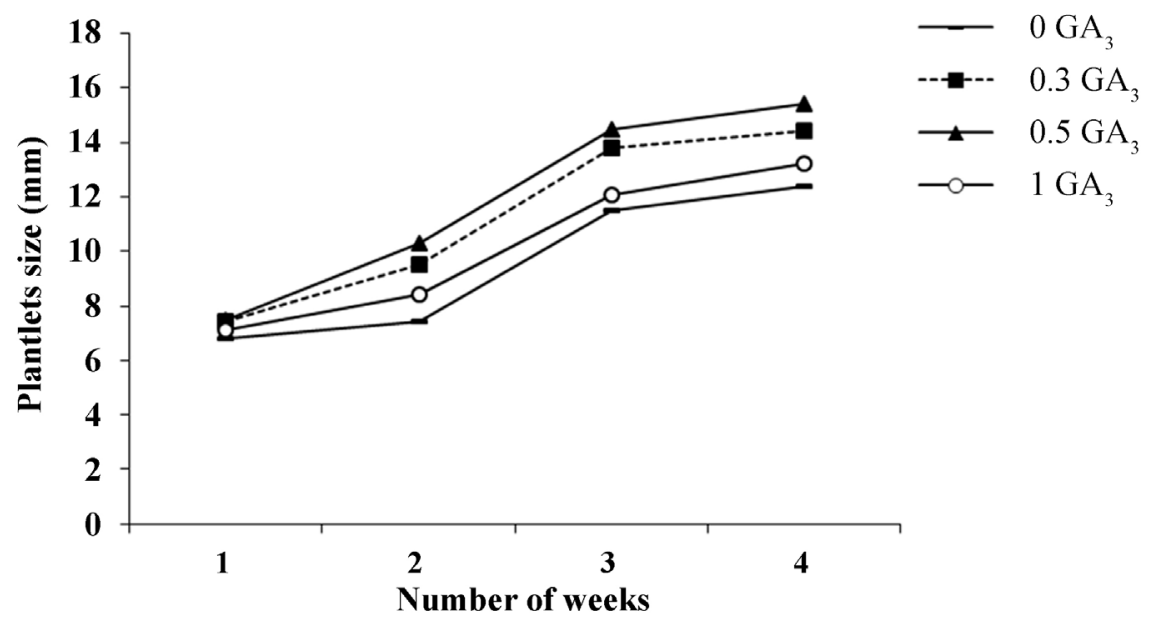

Figure 4. Effect of $\mathrm{GA}_{3}(\mathrm{mg} / \mathrm{l})$ combined to BAP $(0.5 \mathrm{mg} / \mathrm{l})$ on carob shoots elongation in WPM medium during one month.

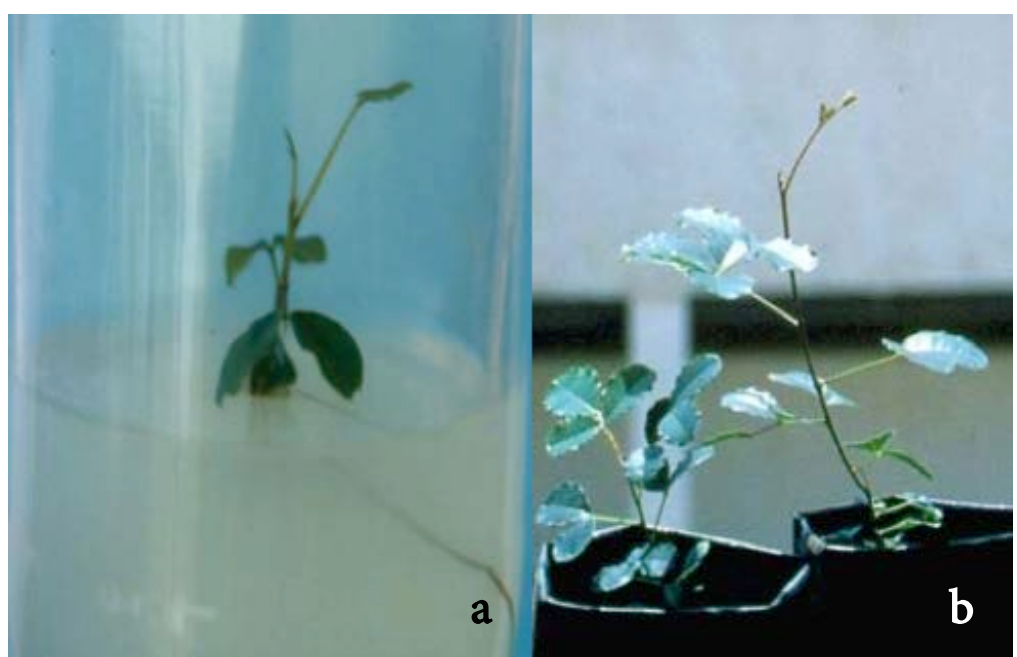

Figure 5. Rooting and acclimatization phases, (a) one-month-old plantlet obtained after culture on 1/2 MS added with $2 \mathrm{mg} / \mathrm{l}$ of IBA; (b) 3-month-old acclimatized plantlets. 
Table 7. Effect of auxins ( 1 and $2 \mathrm{mg} / \mathrm{l}$ ) on carob shoots rooting.

\begin{tabular}{|c|c|c|c|c|c|c|c|}
\hline \multicolumn{2}{|c|}{$\begin{array}{l}\text { Auxins } \\
(\mathrm{mg} / \mathrm{l})\end{array}$} & $\begin{array}{l}\text { Plantlets size } \\
(\mathrm{mm})\end{array}$ & $\begin{array}{c}\text { Shoots } \\
\text { number by } \\
\text { plantlet }\end{array}$ & $\begin{array}{c}\text { Leaves } \\
\text { number by } \\
\text { shoot }\end{array}$ & $\%$ of rooting & $\begin{array}{c}\text { Roots } \\
\text { number by } \\
\text { plantlet }\end{array}$ & $\begin{array}{c}\text { Roots } \\
\text { length }(\mathrm{mm})\end{array}$ \\
\hline \multirow{2}{*}{ IBA } & 1 & $13.3 \pm 1.1 \mathrm{ab}$ & $1.00 \mathrm{c}$ & $6.80 \pm 0.89 \mathrm{ab}$ & $70.00 \mathrm{~b}$ & $6.00 \pm 1.02 \mathrm{a}$ & $65.0 \pm 1.14 \mathrm{a}$ \\
\hline & 2 & $16.4 \pm 1.5 \mathrm{a}$ & $1.73 \pm 0.21 \mathrm{a}$ & $8.16 \pm 1.09 a$ & 89.47 a & $3.76 \pm 0.55 b$ & $61.1 \pm 1.22 \mathrm{a}$ \\
\hline \multirow{2}{*}{ IAA } & 1 & $10.1 \pm 1.2 \mathrm{bc}$ & $1.22 \pm 0.18 b$ & $5.55 \pm 0.95 b c$ & $44.44 \mathrm{c}$ & $1.00 \mathrm{~d}$ & $30.0 \pm 0.78 \mathrm{~cd}$ \\
\hline & 2 & $10.1 \pm 1.1 b c$ & $1.00 \mathrm{c}$ & $4.72 \pm 0.77 \mathrm{~cd}$ & $23.12 \mathrm{de}$ & $1.00 \mathrm{~d}$ & $25.0 \pm 0.42 \mathrm{~cd}$ \\
\hline \multirow{2}{*}{ NAA } & 1 & $11.4 \pm 1.4 \mathrm{bc}$ & $1.18 \pm 0.23 b$ & $3.42 \pm 0.65 \mathrm{~d}$ & $30.18 \mathrm{~d}$ & $2.24 \pm 0.34 \mathrm{c}$ & $48.5 \pm 0.63 \mathrm{ab}$ \\
\hline & 2 & $12.0 \pm 1.2 \mathrm{bc}$ & $1.12 \pm 0.18 b c$ & $4.15 \pm 0.42 \mathrm{~cd}$ & $26.14 \mathrm{de}$ & $1.61 \pm 0.21 \mathrm{~cd}$ & $42.5 \pm 0.86 b c$ \\
\hline \multirow{2}{*}{$2,4-\mathrm{D}$} & 1 & $9.8 \pm 1.3 c$ & $1.00 \mathrm{c}$ & $3.51 \pm 0.53 \mathrm{~d}$ & $23.23 \mathrm{de}$ & $1.50 \pm 0.18 \mathrm{~cd}$ & $21.6 \pm 0.29 \mathrm{~d}$ \\
\hline & 2 & $8.4 \pm 0.9 c$ & $1.00 \mathrm{c}$ & $3.22 \pm 0.44 \mathrm{~d}$ & $20.16 \mathrm{e}$ & $1.27 \pm 0.13 \mathrm{~cd}$ & $18.9 \pm 0.21 \mathrm{~d}$ \\
\hline
\end{tabular}

The data represent mean $\pm S E$ of replicates $(n=3)$. Values in the same rows carrying different letters are significantly different between treatments and compared by Duncan's multiple range tests at $\mathrm{p} \leq 0.05$.

zeatin is the most favorable for shoots elongation, especially at $0.5 \mathrm{mg} / \mathrm{l}$, followed by BAP $(0.5 \mathrm{mg} / \mathrm{l})$ and 2 -iP $(1 \mathrm{mg} / \mathrm{l})$. The efficacy of zeatin and BAP on the growth of various carob explants has been reported by several authors [23] [27] [28] [29].

Nevertheless, the neoformation of shoots and leaves is more favorable in the presence of BAP, especially at $0.5 \mathrm{mg} / \mathrm{l}$, whatever the period of measurement, followed by zeatin, while kinetin and 2-iP are the most unfavorable. These results are in concordance with those obtained by other researchers who have worked on different types of buds of this species [27] [28] [29]. In addition, good results have been reported in some publications for 0.1 [21] and $2 \mathrm{mg} / \mathrm{l}[23]$ of BAP.

Furthermore, this study shows that the combination BAP $(0.5 \mathrm{mg} / \mathrm{l})+\mathrm{AIB}$ $(0.1 \mathrm{mg} / \mathrm{l})$ is the most adequate. Over $0.5 \mathrm{mg} / \mathrm{l}$ of BAP, bloomed buds show more physiological disorders, such as apical necrosis, foliar necrosis and the appearance of lenticels. Similarly, fixing BAP concentration at $0.5 \mathrm{mg} / \mathrm{l}$ and increasing that of IBA favor callogenesis at the expense of caulogenesis. Researchers working on shoots derived from apex [24] or immature embryonic epicotyls [30] achieved similar results. They were also confronted with problems of plantlets hyperhydricity in the presence of high concentrations of BAP. Some authors [31] have added $\mathrm{GA}_{3}$ to this combination and obtained a good development of micro-cuttings from an adult tree.

Therefore, initiation of the culture of different types of carob explants can be easily established in the presence of moderate cytokinin concentrations close to $0.5 \mathrm{mg} / \mathrm{l}$, in particular zeatin and BAP, alone or in combination with low concentrations of IBA $(0.1 \mathrm{mg} / \mathrm{l})$.

Compared with MS macronutrients, those of WPM allow better shoots and leaves formation, in agreement with previously published studies on carob [21] [23] [24]. The combination of BAP $(0.5 \mathrm{mg} / \mathrm{l})$ with different $\mathrm{GA}_{3}$ concentrations 
improved slightly shoot size, while organogenic activity decreased a little, but BAP $(0.5 \mathrm{mg} / \mathrm{l})+\mathrm{GA}_{3}(0.5 \mathrm{mg} / \mathrm{l})$ combination gives healthy shoots without physiological disorders and the use of BAP alone is sometimes accompanied by leaves yellowing and necrosis, especially at high concentrations. In reality, the combination of BAP at moderate concentrations with low concentrations of $\mathrm{GA}_{3}$ has been used successfully [28] [32] [33] during shoot multiplication phase from various carob explants, while we reported negative effect of this combination on shoots multiplication from cotyledonary buds [29]. Consequently, propagation of carob shoots derived from apex is better on WPM medium in the presence of BAP $(0.5 \mathrm{mg} / \mathrm{l})$ alone or in combination with $\mathrm{GA}_{3}(0.5 \mathrm{mg} / \mathrm{l})$.

Shoots rooting after the propagation phase is more favorable in the presence of IBA, especially at $2 \mathrm{mg} / \mathrm{l}$, whereas with the other auxins, rooting rate is lower. These results are in agreement with several other studies [23] [24] [27] [28] [29] [30] [31] [32] [34] concluding that IBA at $2 \mathrm{mg} / \mathrm{l}$ is the ideal auxin for rooting.

Plantlets acclimatization on peat was sometimes confronted with some problems, such as shoots wilting and leaf necrosis. The acclimatized and periodically watered plantlets remain in good condition for ten to twelve months, but after this period, they begin to undergo foliar necrosis, hence the need to transfer them to the soil of a natural environment. After this, the acclimatized plantlets are well maintained and begin to bloom new buds after three weeks.

\section{Conclusions}

The study of the effect of cytokinins on the culture of carob apex showed that zeatin and BAP at low concentrations $(0.5 \mathrm{mg} / \mathrm{l})$ are the most favorable for shoots elongation, as well as for neoformation of shoots and leaves. In addition, initiation of the culture of carob apex can be easily established in the presence of moderate BAP concentration, close to $0.5 \mathrm{mg} / \mathrm{l}$, alone or in combination with low concentrations of IBA $(0.1 \mathrm{mg} / \mathrm{l})$. Furthermore, WPM macronutrients allow better formation of shoots and leaves than those of MS and, the incorporation of BAP at moderate concentrations, combined with low concentrations of $\mathrm{GA}_{3}$, improved slightly shoots size and gives healthy shoots without physiological disorders. Moreover, the addition of $2 \mathrm{mg} / \mathrm{l} \mathrm{IBA}$ alone to MS medium ensures the best shoots rooting. Finally, to achieve acclimatization, twelve-month-old acclimatized plantlets on peat must be transferred to the soil of a natural environment, in order to avoid shoots wilting and leaves necrosis.

The micropropagation of carob tree by apex culture is an effective tool for mass propagation and conservation of this important and rare medicinal plant in Morocco. Nevertheless, the choice of the optimal compositions of the culture media is essential to succeed in this protocol.

\section{Acknowledgements}

This work is carried out as part of the project in the priority areas of scientific research and technological development (PPR2/2016/35), financed by the Min- 
istry of National Education, Vocational Training, Higher Education and Scientific Research, as well as the National Center for Scientific and Technical Research (CNRST, Morocco).

\section{Conflicts of Interest}

The authors declare no conflicts of interest regarding the publication of this paper.

\section{References}

[1] Lo Gullo, M.A. and Salleo, S. (1988) Different Strategies of Drought Resistance in Three Mediterranean Sclerophyllous Trees Growing in the Same Environmental Conditions. New Phytologist, 108, 267-276. https://doi.org/10.1111/j.1469-8137.1988.tb04162.x

[2] Correia, P.M. and Martins-Loução, M.A. (1994) Preliminary Studies on Mycorrrhizae of Ceratonia siliqua L. New York Botanical Gardens: Mycorrhizas in Integrated Systems from Genes to Plant Development. New York, 86-88.

[3] Russo, G. and Polignano, G.B. (1996) Variation of Seed and Fruit Characters in Ceratonia siliqua L. Cultivars. Genetic Resources and Crop Evolution, 43, 525-531. https://doi.org/10.1007/BF00138829

[4] Batlle, I. and Tous, J. (1997) Carob Tree. Ceratonia siliqua L. International Plant Genetic Resources Institute, Rome.

[5] Ait Chitt, M., Belmir, H. and Lazrak, A. (2007) Production de Plants Sélectionnés et Greffés de Caroubier. Bulletin Mensuel d'Information et de Liaison du PNTTA, Transfert de Technologie en Agriculture $\mathrm{N}^{\circ} 153$. Royaume du Maroc, Ministère de l'Agriculture et de la Pêche Maritime, $4 \mathrm{p}$.

[6] Boudy, P. (1952) Guide du Forestier en Afrique du Nord, Ed. La Maison Rustique, $505 \mathrm{p}$.

[7] Lecompte, M. (1969) La Végétation du Moyen Atlas Central, Esquisse Phytoécologique et Carte des Séries de Végétation au 1/200.000. Travaux de l'Institut Scientifique Chérifien et de la Faculté des Sciences, Série Botanique et Biologie Végétale, N³1 Rabat, 34 p.

[8] Ouchkif, M. (1988) Etude sur le Caroubier. Append Number 8 of Project Oued Srou. MARA (Morocco)-GTZ (Germany), DPA of Khenifra. 42 p. (unpublished results).

[9] Aafi, A. (1996) Note Technique sur le Caroubier (Ceratonia siliqua L.). Centre National de la Recherche Forestière, Rabat (Maroc), 10 p.

[10] Gharnit, N., El Mtili, N., Ennabili, A. and Sayah, F. (2004) Floral Characterization of Carob Tree (Ceratonia siliqua L.) from the Province of Chefchaouen (NW of Morroco). Moroccan Journal of Biology, 41-51.

[11] Khlifa, M., Bahloul, A. and Kitane, S. (2013) Determination of Chemical Composition of Carob Pod (Ceratonia siliqua L) and Its Morphological Study. Journal of Material and Environmental Sciences, 4, 348-353.

[12] El Hajaji, H., Farah, A., Ennabili, A., Bousta, D., Greche, H., El Bali, B. and Lachkar, M. (2013) Etude Comparative de la Composition Minérale des Constituants de Trois Catégories de Ceratonia siliqua L. Journal of Material and Environmental Sciences, $4,165-170$.

[13] Sebai, H., Souli, A., Chehimi, L., Rtibi, K., Amri, M., El-Benna, J. and Sakly, M. (2013) 
In Vitro and in Vivo Antioxidant Properties of Tunisian Carob (Ceratonia siliqua L.). Journal of Medicinal Plants Research, 7, 85-90.

[14] El Bouzdoudi, B., Saïdi, R., Embarch, K., El Mzibri, M., Nejjar, E.A.Z., El Kbiach, M. L., Badoc, A., Patrick, M. and Lamarti, A. (2017) Mineral Composition of Mature Carob (Ceratonia siliqua L.) Pod: A Study. International Journal of Food Science and Nutrition Engineering, 7, 91-103.

[15] El Bouzdoudi, B., Ammouri, N., Joly, N., Martin, P., Saïdi, R., Nejjar, E.A.Z., Bouras, M., Badoc, A. and Lamarti, A. (2017) Total Polyphenols and Gallic Acid Contents in Domesticated Carob (Ceratonia siliqua L.) Pods and Leaves. International Journal of Pure and Applied Bioscience, 5, 22-30. https://doi.org/10.18782/2320-7051.5344

[16] Evreinoff, V.A. (1947) Le Caroubier ou Ceratonia siliqua L. Revue International de Botanique Appliquée et d' Agriculture Tropicale, 27, 389-401. https://doi.org/10.3406/jatba.1947.2081

[17] Johnsen, S., Bruun, P. and Okkala, P. (1988) Application of LBG in Food and Pet Food Systems. In: Fito, P. and Mulet, A., Eds., Proceedings of the II International Carob Symposium, Valencia, Spain, 577-587.

[18] Neukom, H. (1988) Carob Bean Gum: Properties and Applications. In: Fito, P. and Mulet, A., Eds., Proceedings of the II International Carob Symposium, Valencia, Spain, 551-555.

[19] Rejeb, M.N. (1995) Le Caroubier en Tunisie: Situations et Perspectives d'AméliorationQuel Avenir pour l'Amélioration des Plantes? AUPELF-UREF Ed., John Libbey Eurotext, Paris, 79-85.

[20] El Batal, H., Hasib, A., Ouatmane, A., Boulli, A., Dehbi, F. and Jaouad, A. (2013) Yield and Composition of Carob Bean Gum Produced from Different Moroccan Populations of Carob (Ceratonia siliqua L.). Journal of Material and Environmental Sciences, 4, 309-314.

[21] Gharnit, N. and Ennabili, A. (2009) Essais Préliminaires de Culture in Vitro du Caroubier (Ceratonia siliqua L.) Originaire du Nord-Ouest du Maroc. Biomatec Echo, 3, 18-25.

[22] Naghmouchi, S., Khoudja, M.L., Romero, A. and Boussaid, M. (2012) Micropropagation of Carob, Ceratonia siliqua L., by Apex Culture. Acta Botanica Gallica, 159, 357-361. https://doi.org/10.1080/12538078.2012.737124

[23] Radi, A., Echchgadda, G., Ibijbijen, J. and Rochd, M. (2013) In Vitro Propagation of Moroccan Carob (Ceratonia siliqua L.). Journal of Food, Agriculture and Environment, 11, 1103-1107.

[24] Saïdi, R., El Bouzdoudi, B., Kbiach, M.B., Lamarti, A. and Maouni, A. (2015) Effets des Macroéléments et des Auxines sur la Micropropagation du Caroubier (Ceratonia siliqua L., Leguminosae) par Culture d'Apex. Journal of Material and Environmental Sciences, 6, 2330-2337.

[25] McCown, B.H. and Lloyd, G. (1981) Woody Plant Medium (WPM)-A Mineral Nutrient Formulation for Microculture of Woody Plant Species. HortScience, 16, 453-453.

[26] Murashige, T. and Skoog, F. (1962) A Revised Medium for Rapid Growth and Bioassays with Tobacco Tissue Culture. Physiologia Plantarum, 15, 473-497. https://doi.org/10.1111/j.1399-3054.1962.tb08052.x

[27] Romano, A., Barros, S. and Martins-Loução, M.A. (2002) Micropropagation of the Mediterranean Tree Ceratonia siliqua. Plant Cell, Tissue and Organ Culture, 68, 35-41. https://doi.org/10.1023/A:1012912504288 
[28] Saïdi, R., Lamarti, A. and Badoc, A. (2007) Micropropagation du Caroubier (Ceratonia siliqua) par Culture de Bourgeons Axillaires Issus de Jeunes Plantules. Bulletin de la Société de Pharmacie de Bordeaux, 146, 113-129.

[29] Saïdi, R., El Bouzdoudi, B., El Kbiach, M.B., Maouni, A., Badoc, A. and Lamarti, A. (2016) Micropropagation du Caroubier (Ceratonia siliqua L.) par Culture de Bourgeons Cotylédonaires. Journal of Material and Environmental Sciences, 7, 4850-4859.

[30] Vinterhalter, D. and Vinterhalter, B. (1992) Factors Affecting in Vitro Propagation of Carob (Ceratonia siliqua L.). Archives of Biological Sciences, 44, 177-186.

[31] Naghmouchi, S., Khouja, M.L., Rejeb, M.N. and Boussaid, M. (2008) Effect of Growth Regulators and Explant Origin on in Vitro Propagation of Ceratonia siliqua L. via Cuttings. Biotechnology, Agronomy, Society and Environment, 12, 251-258.

[32] Belaizi, M., Bolen, M.R. and Boxus, P. (1995) Régénération in vitro et Acclimatation du Caroubier (Ceratonia siliqua L.). In: Dubois, J., Ed., Quel avenir pour lamélioration des plantes? John Libbey Eurotext, Inc., Paris, 227-232.

[33] Hakim, L., Islam, M.R., Mamun, A.N.K., Ahmed, G. and Khan, R. (2010) Clonal Propagation of Carob (Ceratonia siliqua L., Fabaceae). Bangladesh Journal of Bota$n y, 39,15-19$. https://doi.org/10.3329/bjb.v39i1.5520

[34] El Bouzdoudi, B., Saïdi, R., Nejjar, E. A. Z., El Kbiach, M.B., Martin, P., Badoc, A. and Lamarti, A. (2017) Micropropagation of Carob (Ceratonia siliqua L.) through Adventitious Buds of Immature Embryonic Cotyledons. American Journal of Plant Sciences, 8, 2180-2195. https://doi.org/10.4236/ajps.2017.89146

\section{Abbreviations \\ WPM: Woody Plant Medium \\ MS: Murashige and Skoog \\ PGR: Plant Growth Regulators}

